\title{
The Process of Pregnancy: Paradoxical Temporalities of Prenatal Entities
}

\section{Laura Völkle ${ }^{1}$ (D) Nico Wettmann ${ }^{2}$}

Accepted: 1 June 2021 / Published online: 27 July 2021

(c) The Author(s) 2021

\begin{abstract}
In this article, we reflect on the particular temporal structure of pregnancies and prenatal entities with the aim to contribute to the field of the sociology of pregnancy. Medical models and technology shape today's notion of pregnancy as a linear, nine-month developmental process that leads to the birth of a child. Through ultrasound technology and prenatal examinations, prenatal entities have thus historically gained a present 'being' as a developing, unborn child. While these ideas undoubtedly greatly influence the participants' interpretations, a culturalistic perspective on time alone does not do justice to the phenomenon's lived tensions and the temporal complexity of the phenomenon. From a Schutzian perspective of time, we have worked out how practices of pregnancy and the production of meaning are shaped by an interwoven back and forth between orientations to the past, present and future. Drawing on relevant works from the sociology of pregnancy, we work out five modes of temporal references that mold the phenomenon of pregnancy: joint imagination of the couple, in which the (un)born is anticipated as fantasies of the future (1), passivities of pregnancy, in which the desired future is experienced as unable to influence (2), the presentification of the unborn in and through visual and bodilysomatic contact moments (3), its futurization through the cultivation of a 'not-yet' (4) and prenatal losses, as a critical rupture with the anticipated and desired future (5). Our analysis underlines the potential of a time sociological perspective on pregnancy and the constitution of relationships and persons.
\end{abstract}

Keywords Sociology of pregnancy · Temporality · Alfred Schutz · Unborn · Pregnancy loss

Laura Völkle

lavoelk1@uni-mainz.de

Nico Wettmann

nico.wettmann@sowi.uni-giessen.de

1 Institute of Sociology, Johannes Gutenberg-University (JGU) Mainz, Jakob-Welder-Weg 12, 55128 Mainz, Germany

2 Institute of Sociology, Justus Liebig University Giessen, Karl-Glöckner-Str. 21E, 35394 Gießen, Germany 


\section{Introduction}

Pregnancies are characterized by a particularly strong orientation towards the future: future parents are expecting a child. Since the medicalization of pregnancy, prenatal entities ${ }^{1}$ appear in the form of embryos and fetuses as present objects that are examined using prenatal diagnostics to determine their current condition. Despite their presentifying aspects, however, these knowledge objects do not seem to lose their future-oriented reference: although the medical sex determination refers to the present fetus, the intention is to provide information about "what it will be" and not "what it is" (Heimerl 2013: 168). ${ }^{2}$ This particularity of future occurrences is even clearer in the case of the discovery of unintended pregnancies when the question of a continuation or termination arises. In this case, the (assumed) future of the prenatal entity determines its current status: as either a lump of cells and a "tumoral foetus" or as an "authentic foetus" (Boltanski 2013), which refers to the parent's child, that it is to become. Prenatal diagnostics seem to be mainly prognosis of the postnatal, whereas (non-)parental projections of biographies and life plans primarily determine what the current prenatal entity $i s$. These seemingly paradoxical temporal references are further affected by the uncertainty of a pregnancy's future: it may always turn out differently, and the pregnancy could end in a miscarriage.

Current works in the field of the sociology of pregnancy deal with temporal aspects of the phenomenon in a variety of ways: they conceive pregnancies as a social process in the form of an "expectations arc" [Erwartungsbogen], in which the constitution of a child is worked on in different ways and over several stages of acquisition (Hirschauer et al. 2014). This takes place in the form of a joint "becoming" (Schadler 2013) and passive happening determined by "allowing, letting through, letting come close" (Fischer 2011: 35). Cultural-historical and medicalsociological studies emphasize the contribution of medical models and technologies to today's notion of pregnancy as a continuous developmental process, in which an embryo develops into a child ready for birth over the course of nine months (DiCaglio 2017; Duden 1993). In these works, however, the theme of temporality remains quite indirect and theoretically less elaborated. What is seen as a systematic absence in the sociological theoretical discourse (Lindemann 2016; Luhmann 1979), also applies to the sociology of pregnancy: a systematic connection to the sociology of time, the future, and reflections on the role of temporality for the social remains missing.

Our article aims to make this connection by bringing together relevant studies' findings to work out the specific temporalities of prenatal entities and systematically examine the temporality of pregnancy: a discontinuous concept of temporality, as an entanglement between different temporal references and simultaneity of past,

\footnotetext{
1 "Embryo, fetus, baby [...] all these reflect quite arbitrary meanings which correspond neither to biological nor developmental realities" (Montagu 1989: 98). Therefore, we use 'prenatal entities' as an analytical term that leaves open what this entity is and allows for an analysis that focuses on the change of meaning over the course of events.

2 All German citations have been translated by the authors.
} 
present and future. We first present three different sociological perspectives on time and combine them with the phenomenon of pregnancy: an objectivistic understanding of time forms the background for understanding the historical change of pregnancies. Building on this, but going beyond it, medicalization research uses a culturalistic understanding of time and has worked out how medical time regimes gave rise to the idea of pregnancies as nine-month biological development processes. Perspectives, that view time as a genuine part of the social, enable a better understanding of the core of the phenomenon: the focus of interest in current works in the field of sociology of pregnancy lies in the process of "becoming of persons and relationships" (Hirschauer et al. 2014: 261), but has not yet been systematically considered from a time-sociological perspective. With recourse to relevant sociological and cultural studies, we take the "specious present" (Schutz 1959) of different pregnancy moments as a starting point and show the simultaneity and back and forth of different temporal references. In this sense, it is not only scientific processes, that go through a zig-zag course of development (Fleck 1979), but pregnancy and prenatal entities as well. Finally, we will summarize our results and present an understanding of pregnancy as a phenomenon of beginning.

\section{Time-Sociological Perspectives on the Phenomenon of Pregnancy}

Within the field of sociology, ${ }^{3}$ roughly three different understandings of time can be distinguished (Reckwitz 2016: 117ff.; Burzan and Schöneck 2002): an objectivist understanding of time (1) assumes the existence of a linear, chronological calendar time, forming the background for all events. It can be measured using standardized time measurements such as years, weeks, and minutes. Such an understanding of time is often implicitly carried along and used in the cultural and social sciences to identify historical change and make appropriate time diagnosis (e.g., Beck 1992; Reckwitz 2020) or investigate the 'use' of time in time budget studies (e.g., Kreyenfeld and Schulz 2018). This perspective, within pregnancy research, allows us to consider that pregnancies today - unlike in the past - are carried out as projects of an "entrepreneurial self" (e.g., Villa et al. 2011: 11) or that pregnancies can be diagnosed increasingly earlier in the historical course (e.g., Duden 1993).

A culturalistic understanding (2) of time goes one step further. Here, time is not (only) thought of as an objective framework, but the focus lies on cultural influences on the conception and perception of time, meaning that time is understood as a social and cultural category (Sorokin and Merton 1937). Durkheim (1995: 9f.) already described the emergence of calendar time as a social category of thought for social rhythmization and thus, regulating and routinizing collective activities. In the cultural studies of pregnancy research, several works can be found that deal with the historical development of pregnancy knowledge. These address the temporal order of pregnancy weeks and trimesters, as well as the associated idea of continuous development from a germ cell to the birth-ready fetus, as contingent

\footnotetext{
${ }_{3}^{3}$ For a comprehensive overview, see Bergmann (1992), Subrt (2001).
} 
cultural concepts. Most notably, Duden (1993, 2002) reconstructs how medicalization replaced pregnant women's embodied knowledge with an objective view from the natural sciences. Medicalization and its objectifying view, brought with it an abstract, nominalistic conception of pregnancy and the unborn, that is closely related to the contemporary embryonic development model and the medical 'timing' of pregnancy: up until the eighteenth century, pregnancies were regarded to as a state of good hope for the hidden maturation of a child, at the end of which it could just as well turn out to be "a moon child, a mole, a blood burden" (Duden 2002: 39). Thus "the truth of a present pregnancy [...] had to prove itself only in the future, in 'birth'. What the woman (now) carried within her and whether she was pregnant with a child still had to be revealed" (Duden 2002: 17). The "staging" of embryos played an essential role in the rise of the idea of a linear development process. In the early twentieth century, scientists started to bring embryos of different sizes into a temporal order, establishing embryonic stages in medical models. This has contributed to charging pregnancy with anticipation so that prenatal entities were now considered humans in development whose (normative) timely development can and should be examined regularly (DiCaglio 2017). Beyond that, the visualization of the unborn through ultrasonography supports its status as a present entity: 'The child' can already 'be here' in ultrasound examinations. Orland (2003) interprets this development as the social 'birth' of a child being brought forward in time and thus touching upon the question of the limits of the social (Lindemann 2002; Luckmann 1970). Speaking with Duden, the truth of pregnancy no longer emerges only at birth, but to a certain extent already during pregnancy control examinations.

The third group of sociological works understood temporality as a genuine part of the social, so time is regarded as a pivotal element in social theories (3). From this perspective, social phenomena, such as pregnancy and the transition to parenthood, are not only shaped by cultural conceptions of time but are always already temporally structured, as they are ongoing processes- they can only be understood when considering this. Husserl (1928/2000), for example, describes consciousness as inherently temporalized, as an ongoing stream of experience. The present experience, as a reference point for his phenomenological reductions, is still structured by "retentions" and "protentions," meaning, by impressions from previous experiences and by expectations of subsequent experiences: when hearing a melody, the single tone is not only perceived for itself, but it gets its respective sound by the retentions and protentions of the past and following tones. This idea is also found-pragmatically inspired and sociologized-in Alfred Schutz's theory of action. Schutz also assumes a "specious present" (Schutz 1959: 86), structured by references to the past and anticipations of future experiences. The respective horizon of this specious present is constituted on the one hand, by the earliest past experience still relevant for my present projecting; on the other hand, by the span of my projects, the temporally remotest future acts, I anticipate (Schutz 1959: 86f.). In the acting now, the temporal references are thus intertwined: "The wide-awake self integrates in its working and by its working its present, past, and future into a specific dimension of time" (Schutz 1945: 537). To varying degrees, expectations for future experiences are structured by typification and past experience. For example, we know with great certainty that the sun will rise tomorrow. Simultaneously, however, expectations regarding 
future events always have an open horizon: they are never congruent with what will once have happened (Schutz 1959: 88). And although Schutz understands the idealizations of "and so forth and so on" and "I can do it again" (Schutz 1959: 80) as assumptions of consistency, which build on past experience and knowledge, the past does not necessarily have a determining effect but offers a framework of possibilities. In the same way, Schutz's contemporary Mead, succinctly formulated that "all pasts are as essentially subject to revision as the futures, and are, therefore, only possibilities" (Mead 1926: 84). In this conception, linear thinking of time is replaced by sensitivity to discontinuities and alterable meaning that changes throughout the process because remembered past experiences and expected future ones are modified by current relevances, which are structured by references to remembered past experiences and expected future experiences.

Such a concept of time, starting from present moments and making discontinuities conceivable, seems to be central to understanding pregnancy in its temporal complexity, which emerges from its properties as a process of becoming. The phenomenon of abortion demonstrates this: according to Boltanski (2013), whether a prenatal entity is considered a proliferation of cells or a future child, depends on the question if it is part of a 'parental project'. With Schutz, the respective (and during the ongoing process, changing) projected futures of the pregnant couples are significant for the possible (not) becoming of persons. However, this genuine temporality remains conceptually undeveloped in Boltanski's work, as he focuses on the moral dimension of decision, with his dualism of engendering "through flesh" and "through speech" (2013: 61).

In other works on the sociology of pregnancy temporal aspects play a greater role. For example, almost all empirical studies have a process-oriented research design and process-oriented analytical concepts. Schadler (2013), for instance, posthumanistically conceives pregnancy as a transformative process of a material assemblage, where becoming father, mother, child takes place. Fischer pleads for a passivistic view of pregnancy since it is "intermittently happening" [ein schubweises Geschehen] (2011: 24). However, the temporality aspect of becoming and happening remains implicit. Only Hirschauer et al. examine the "metamorphosis of expectations and reconstructions, projections and reprojections" (2014: 13). They conceive an ideal-typical "expectations arc," that develops and extends beyond birth, through the interplay of competing times: inner and outer times, the proper time of the unborn, as well as a medical time regime acting as the external frame (Hirschauer et al. 2014: 263). Here, expectations "are constructed prospective-retrospectively with time and reconstructed in time" (Hirschauer et al. 2014: 262).

With our article, we connect to such an understanding of pregnancies open to temporal discontinuities, and expand the sociological analysis of time, based on a broader state of research and by linking our considerations to Schutz. Thus, our contribution aims at demonstrating the analytical potential of a time-sociological approach to pregnancy. Contemporary ideas of development also influence the phenomenon of pregnancy, and these affect the interpretations of the actors involved. To do justice to the complex temporal relationships in which individuals and families are created, it is worth looking at the processually evolving re/construction of meaning that is accomplished by the pregnancy ensemble. We therefore suggest, analysis 
of pregnancies taking a more intense look at this complexity and entanglement of time. Prenatal entities are then, as we will show in the following, present and future beings.

\section{Paradoxical Temporalities}

In the following, we want to develop our approach: the temporality of the unborn and pregnancy as paradoxical temporalities. For this, we have reviewed and combined relevant works from the sociology of pregnancy, research on medicalization, and the transition to parenthood. We partly adopt the theoretical concepts and analyses from these works and/or sharpen them from a perspective of time sociology and, in parts, use the empirical data shown by subjecting it to a kind of socio-temporal reanalysis. The temporality of pregnancies that we have worked out in this way, constitutes itself as an interwoven back and forth between different temporal references and concurrence of past, present, and future relations. The practices of pregnancy and the production of meanings by (co-)pregnants ${ }^{4}$ exhibit temporal orientations, in which the ontological status of the prenatal entity fluctuates between different forms of not yet and already. Thus, we distinguish between five modes of temporal references ${ }^{5}$ molding the phenomenon of pregnancy: joint imagination of the couple, in which the (un)born is anticipated as fantasies of the future (1), being exposed to the passivity and uncertainty of pregnancy, in which the desired future is perceived as unable to influence (2), the presentification of the unborn in and through visual and bodily-somatic contact moments (3), its futurization through the cultivation of a 'not-yet' (4) and prenatal losses, as a critical break with the anticipated and desired future (5).

\section{Parental Imaginations}

From their very beginning pregnancies are characterized by a future-oriented approach: whether an unexpected pregnancy is discovered, or the possibility of a not yet physically existing pregnancy begins to take shape, parental and/or non-parental futures always play a crucial role. But what kind of future reference is this? In family research, rational choice approaches ${ }^{6}$ have long been and continue to be predominant. Pregnancies are seen as a result of decisions made after weighing up different expected futures and their costs and benefits. However, interpretative social research has expressed doubts about this concept. For example, Burkart (2002: 28f.) argues

\footnotetext{
4 This term refers to all those persons who are involved in the process of pregnancy and thus occur as "carriers of worries, information and expectations" (Hirschauer et al. 2014: 77).

5 Our analysis is based on an ideal-typical temporal course of pregnancies. The temporal references that we work out will never completely supersede each other, even if we show a linear understanding of time for the benefit of clarity.

${ }^{6}$ Lindemann (2016) critiques the normative universalization of a benefit-oriented reference to the future, such as the Rational Choice Theory.
} 
that, with such a benefit-oriented approach and because of the overwhelming countless possibilities, it would never come to a decision being made. Burkart even questions the assumption that pregnancy is based on decisions, in the sense of selecting alternative actions. Using Schutz's concept of "life plans," he suggests paying attention to the close connection between such future references and the identities of the actors that are realized in them: a "life plan" does not refer to "sequential planning of events," but to "the abstract idea of a good life, [the] project of an identity" (Burkart 2002: 41). For Burkart, the beginning of pregnancies is less a decision for an expected (and best possible) future option, but rather "it is a search, a work on one's own identity - on the realization of projects, on small and big decisions that lead in a certain direction, but there is always a great deal of uncertainty about what one 'chooses' will actually look like in the end, how the path continues and where it leads to" (Burkart 2002: 43). Consequently, Burkart argues that the 'decision' to have children should not be attributed to individual actors. What should be investigated is the interactive processes, in which the coordination of a couple's developing life plans takes place (Burkart 2002: 42).

Similarly, Heimerl and Hofmann ask: How does a desire to have children come into the couple's relationship? (2016: 419). Using individual case analysis to approach this question, they examine how a couple can approach pregnancy through "future fantasies, conversations in the context of couple communication or among friends, about allusive expectations of potential grandparents" (Heimerl and Hofmann 2016: 419). Because having children is a genuine couple's matter of the greatest importance, the communicative efforts introducing a child as a common perspective for the future, require a sure instinct, and the topic needs to be dosed skillfully (Heimerl and Hofmann 2016: 420). With Schutz, this process can be described in the following way: initial addressing of the topic can take the form of open phantasying, which does not aim at "carrying out the project" (Schutz 1959: 85). In this way, a child can be playfully brought into a couple's communication as a fantasy of the future. If this communicatively planted fantasy is taken up by the partner, a "mutually oriented intersubjective makebelieve play" (Schutz 1945: 559) can develop. The imagining of the child and being a parent can continuously take on new forms due to the innocent playfulness of the imaginations. The imagined child can be a boy or a girl, the father could stay at home or go back to work early on. ${ }^{7}$ Yet, such fantasies of the future gain veracity through the couple's intersubjectivity. They shift from "optative" towards "potentialis". Schutz distinguishes "pure phantasying" as "thinking in the optative mode" from "motivated phantasying" (Schutz 1951: 165), which characterizes plans of action as an "imagined performed act, imagined in the future-perfect tense" (Schutz 1945: 556). When examining the development of a desire for a child and pregnancies, such a clear distinction seems misplaced.

\footnotetext{
7 Such an open fantasizing continues even with a positive pregnancy test and is often preserved until late in the pregnancy by cultivating open futures (see below). If a couple forgoes a sex determination during pregnancy, for example, they can still play through different male and female child biographies for a long time (Hirschauer et al. 2014: 211).
} 
Open phantasying about a future child often marks the beginning of the process of having a child, can become denser, and prepare the ground for possible plans and projects - for example, for the targeted "tinkering" with a pregnancy. Heimerl and Hofmann (2016: 422) even show that the development of pregnancies is not necessarily dependent on such targeted actions, but that pregnancies can be better understood as a distributed process, in which the alleged actors are merely participants in a co-active occurrence, also involving bodies and artifact. Therefore, pregnancies can not only be induced in a targeted manner but they can also be allowed or simply not prevented. For us, imagination of the future, which can condense, change, and vanish in couples' interaction, seems to be a significant participant in this process.

But is there a point at which an imagined future suddenly becomes serious? The surprise and shock that many couples experience at the sight of a positive pregnancy test (e.g., Heimerl and Hofmann 2016: 422)—even when they have deliberately pursued pregnancy — can, with Schutz, be understood as a leap between provinces of meaning: the pregnancy changes from the world of phantasms to the "paramount reality" (Schutz 1945: 549) of the everyday world. Being parents and having children, although still in the future, is suddenly felt as inevitably approaching. However, during the course of a pregnancy there are many other moments of this kind; The pregnancy and the unborn shift between future phantasms and present reality repeatedly. Such moments of shock discard parental phantasms and have to be (re) formulated into the everyday world to stabilize the pregnancy's entities. Furthermore, the phantasms of the child stimulate further imagination related to one's parenting with the expected child. Imaginations are also references of parental concepts that are constantly compared with the pregnancy's current development and course. For example, ideas about the child's gender produce parental imaginaries about gender-specific behaviors of the expected child or the couples' expectations about their role as parents. Throughout the course of a pregnancy, past phantasms of the future are constantly compared with the present and with an imagined future to (re)formulate one's own identity as a parent and that of the unborn. The desire to have children can thus not only be understood as an "in-order-to motive" which refers to "the pre-phantasied state of affairs to be brought about by the future action" (Schutz 1951: 163). Rather, references back to the past and past phantasms are also significantly involved: "With the beginning of a pregnancy, the past and future of couple relationships are simultaneously charged. The couple can no longer focus only on a shared present. It is stimulated much more strongly than usual to design a joint future as well, which is ideally supported by a shared construction of its past" (Hirschauer et al. 2014: 61). Regarding the concatenation of motives for action, it can then also be argued that the "because-motive" (Schutz 1951: 163) thus does not only refer to past experience, but also to past imagination. This important relationship of fantasies for the social is also emphasized by Strauss (1959): according to this, phantasms are preparatory, are everyday aids and review, as well as reformulations of the past - they can then have a direct effect on action but are not necessarily so. Phantasm thus also refers to a collision of temporality in which the fantasized futures coincide with the living present and accordingly affect the projects of action and identities. 


\section{Waiting, Worrying, Hesitating: Passivities of Pregnancy}

A feeling of being exposed to processes outside of one's sphere of action can also manifest itself in waiting. Schutz and Luckmann themselves refer to pregnancies to point out the phenomenon of waiting and its special temporality: „The pregnant woman must wait until the time of the delivery. [...] In waiting we encounter a time structure that is imposed on us" (Schutz and Luckmann 1973: 48). Since the awaited event can occur only in a possible future, waiting is "a mode of not yet; it always staggers the relevance on the horizon of what we are waiting for" (Paris 2001: 707). (Co-)Pregnants wait for internal bodily movements, physical changes, or for birth. Moreover, "[w]hile we wait for something, we are dependent on what we are waiting for. It is not we, who end the wait, but the event for which we have been waiting" (Paris 2001: 709). Pregnancies are therefore characterized by "forced passivity" (Paris 2001: 707): they cannot simply be deliberately induced or kept intact. Thus, pregnancies are characterized by a temporal mode, in which the openness of the future is experienced as unalterably.

Investigating this aspect of passivity, Fischer describes pregnancy as "happening intermittently: $[\ldots]$ the maturation of the embryo to be awaited and sat out, the contractions that have been induced, and, in general, the experience in which a protosociality imposes itself (the embryo in the body of the other) or, in other words, is pushed into 'something' at birth as a potential 'someone' in a sociality, a someone, in turn, who is inherent in a born growth process" (Fischer 2011: 24). In this conception of pregnancy, phenomena such as medical examinations, ultrasound probes, and birth preparations, do not essentially change "the natural process of being pushed, of giving birth and being born" (Fischer 2011: 33). This passivity also characterizes the ontological status of the unborn: "No generation of mothers knows what or whom they are giving birth to-which human being is in the newcomer: unpredictability and creativity" (Fischer 2011: 34). However, this unpredictability refers to an anticipated future, for which the pregnant couple prepares itself-which speaks for the interdependence of activity and passivity. ${ }^{8}$

In this sense, Schadler (2013) conceptualizes pregnant couples' initial condition, when an anticipated pregnancy is not yet certain, as a form of waiting that manifests itself in an intra-analysis of the body: "Wannabe-pregnant women" pay attention to popular medical signs, such as physical sensations (dizziness, nausea) or changed eating behavior (ravenous appetite, aversions to tastes). During this, they observe their body and its reactions closely, paying attention to repetitions and changes (Schadler 2013: 115f.). The pregnancy is further established via media technologies, such as pregnancy tests, in which hormone content in the urine is tested. If the result is positive, it indicates successful implantation of the blastocyst approximately one

\footnotetext{
${ }^{8}$ From a phenomenological perspective, Bongaerts (2020) argues precisely with Schutz, against the criticism of an activist bias (Fischer 2011; Seyfert 2019) and concludes, "that action never takes place completely actively in the sense of the wide-awake consciously controlled execution of a previously designed plan and that it is also not to be thought without conscious control in passive execution of a somehow produced behavior. It is rather assumed that the relationship between active and passive is usually about overlaps, transitions, and gradual levels differences" (Bongaerts 2020: 143).
} 
week after fertilization (Schadler 2013: 119ff.). In the case of pregnancy, waiting focuses on the perception of physical changes, as a passive waiting for the blastocyst's successful implantation in the uterus. The hormone release, triggered by this implantation, then enables the pregnancy test to be taken, resulting in another waiting (for the result), due to its own technical time.

Passivity can also be understood in terms of intentional not-acting, which "may bring about a future state of affairs by non-interference" (Schutz 1951: 161). Noninterference can be found in the time after the diagnosis of pregnancy. Especially in the beginning the condition and development of the pregnancy and the unborn are overshadowed by passive conditions. Schadler calls this time the phase of "Perhapsability of pregnancy" [Vielleichtheit der Schwangerschaft] (Schadler 2013: 148). Here, pregnant couples abstain from parental imaginations and informing third parties, mainly because of the possibility of a miscarriage, i.e., the uncertain future: although a pregnancy test can "indicate that there is a high probability of an existing pregnancy, it cannot guarantee that it will still exist tomorrow or in two weeks" (Schadler 2013: 149f.). Characteristic for this phase of pregnancy is the restraint of activities: not being happy yet, not talking about it yet, and not shopping yet (Schadler 2013: 155ff.). In this time, pregnancy and the prenatal entity's ontological status are characterized by uncertainties, so that no active participation seems possible but rather inactivity is produced. During this phase, pregnant couples do not act. The ending of this perhapsability begins with attaining a felt security: the future course of events seems more reliable, and the prenatal entity's ontological status changes. The fetus is now being seen as " "real' once and for all," and "real and here and as an entity, that lives in the womb of the expecting mother, but is separable from her" (Schadler 2013:159f.). This is done by exceeding a point in time, a mental fixation, physical changes, or medical personnel's ascriptions.

Pregnancies are thus characterized by passivity, different stages of not being able to do anything, and being exposed to physical processes: "Both my organism and my society impose upon me, and upon my inner time, certain sequences of events that involve waiting. [...] the temporal structure of everyday life is exceedingly complex, because the different levels of empirically present temporality must be ongoingly correlated (Berger and Luckmann 1966: 27). While, in the beginning, there is still uncertainty about the state of the pregnancy and active intervention is not and does not appear to be possible, moments of passivity continue to wait in the further course of the pregnancy: growth of the abdomen, physical sensation, a bodily feeling of inner movements. "Not-yet-activities" (Schadler 2013: 155) maintain an openness of pregnant couples' expectations and, thus, prevent a hasty drawing of conclusions from the potential future to a clear future. To cope with uncertainties, pregnant women observe themselves and compare their current condition retrospectively. By referring back to the past, changes can become tangible, and thus the imposed time structure of the biological development of the pregnancy can be handled. Through the experience-based securing of the pregnancy, the pregnancy's probable nature is transformed into a continuity of pregnancy that is tantamount to the idealization of the "and so forth and so on". The openness of the pregnancy and the prenatal entity, resulting from the futures of the probabilities, thus implies one specific future-at least until proven otherwise. 


\section{Presentification}

With the increasing establishment of pregnancy as a physical fact, moments occur, in which the prenatal entity as such becomes present. In these moments, it is not only a future family member, that is expected but not yet there, appearing on their horizon, but an unborn entering consciousness as a present entity and made tangible. As shown above, medicalization research, and in particular Barbara Duden, has pointed out, from a historical perspective, that visualization in ultrasound examinations functions as a kind of "reality generator in real-time" (Wettmann 2020: 80) and is critical in the presentification of the unborn as an independent entity and developing fetus. Through the technological revealing, the unborn enters into a relationship with the expecting parents that creates a present bond between the couple and the unborn but simultaneously involves responsibilities and decisions about the future (Verbeek 2008: 17). The objectification by ultrasound thus refers first to the potential reality in the "world within attainable reach" (Schutz 1945: 547), to the child that will come into the parents' zone of action in the future. On the other hand, ultrasound technology pushes the unborn child into the "manipulatory area" of the parents in a "world within my reach" (Schutz 1945: 547). With this in mind, the presentification of the unborn and the constitution as a person that it generates thus also leads to an adjustment of parental behavior to minimize the risk to the unborn child: "Furthermore, because of the emphasis on child protection the woman is increasingly seen as being a dangerous influence on the foetus be it through smoking or some other kind of unhealthy life-style" (Zechmeister 2001: 394). Hence, decisions and courses of action must be designed in the present to shape the desired future and minimize risks.

Studies from the sociology of pregnancy also point out the constitution of the unborn, as a present person with view on the temporality: Eva Sänger, for example, shows that co-pregnants can use ultrasound examinations as an occasion to see what the unborn is "currently doing," "what is going on right now" and "what it is up to in that moment" (Sänger 2010: 56). Thus, the visualization-technologies refer to an unborn's present doings, whereby it is interpreted as an acting or reacting person (Sänger 2010: 57). Especially for becoming fathers, such visualizations of the unborn appear as an essential pregnancy event. These men understand ultrasound situations as a "strong memory of pregnancy" and as "evidence of the existence of the baby" (Draper 2002: 780), which is not only accompanied by a development of the child "form 'amorphous blob' to "my baby" (Draper 2002: 785), but also by a transition to fatherhood (Draper 2002: 788). Regarding temporality, Draper concisely concludes: "In making images of the unborn baby available for public viewing, ultrasound proclaims the body to be, and endows the baby with a social identity. This process confuses temporal and corporeal boundaries, as the future is brought into the present and the social precedes the biological birth" (2002: 790). And thought further, such presentificating moments in ultrasound examinations can later be picked up to integrate the unborn visually, narratively, and imaginatively into everyday life as a "family-member-to-be" (Sänger 2010: 58). For example, together with photos of the surroundings from the respective week of pregnancy, ultrasound images are put into an album as memories for the future child (Sänger 2010: 57). 
This clearly represents an example of an "anticipated hindsight" (Schutz 1959: 88). However, a temporal specificity lies in this pregnancy practice: not only the future act of having created the album is anticipated in the form of "modo futuri exacti" (Schutz 1959: 87), but the ultrasound images can only sensibly represent a common past by anticipating that what they depict will one day have been the aspirant of the parents' child. Sonographic generation of reality thus not only takes place 'in realtime', but also through the anticipation of its will-have-been. It is the reference to the future that generates personalizing meaning - a phenomenon which Hirschauer et al. have concisely named with the oxymoron "traces from the future" (2014: 280).

On this account, medicalization research's thesis of the social birth being brought forward through ultrasound technology can, one the one hand, be confirmed: visual representations in ultrasound examinations display "what it is doing right now," and an album with ultrasound images is one day supposed to show "that is how it was back then" (Sänger 2010: 57). Through this, the prenatal entity's life, biography, and affiliation with a family community can already begin prenatally. On the other hand, however, it also becomes clear that this prenatal life's constitution always refers to the future, specifically the future after birth. Only against the background that the prenatal entity will become a child-in the idealization of the "and so forth and so on,"- do the present visual experiences acquire their sense of relationship.

Prenatal presence of the unborn is, however, not only produced by visual probing. Innerbodily sensations, that are understood as announcements of an "inward other" [inwändiger Anderer] (Hirschauer et al. 2014: 94), also bring the prenatal entity into the present. ${ }^{9}$ Compared to the occasional visitations during ultrasound examinations, these sensations enable a more regular and more integrated presentification of the unborn in the pregnant couples' everyday life. When, after initial attribution difficulties ('Is there already someone or is it still my own body?'), the bodily sensations - also against the background of developmental biological knowledge and visual impressions (Sänger et al. 2013: 61) —have become the "other in me" (Hirschauer et al. 2014: 147), many pregnant women begin to consider this other in their current activities: is the current lying position of the jointly shared body or the music currently playing pleasant for the unborn (Hirschauer et al. 2014: 147ff.; Schadler 2013: 243f.)? Bodily noticed movements are understood as the inward other's reactions to ongoing events. They are based on the assumption of a "simultaneous common sensation" [zeitgleiches gemeinsames Empfinden] (Hirschauer et al. 2014: 147) and thus on a jointly shared "vivid present" (Schutz 1945: 540). Although the prenatal entity is not yet born, it is still in the world and in contact with the pregnant woman; they are in a bodily-somatic "We-relation" (Schutz 1945: 543) and share space and time with each other. By typifying certain experiences as reoccurring, preferences and character traits can be ascribed to the unborn. Thus, the unborn could be considered a "lover of specific musical styles" (Schadler 2013:

\footnotetext{
9 The determination of pregnancy knowledge by technical objectification must therefore also be rejected. Rather, the knowledge of the pregnant is formed by the relation of subjective perception and objectified ultrasound image, which is why the sonographer must reconcile both spheres in the ultrasound situation (Heimerl 2013; Rentmeester and Hogan 2020).
} 
244). Such prenatal characterizations can, in turn, provide pregnant couples with occasions for rituals, such as winding a music box in the evening. On the one hand, such rituals refer to the present unborn with its present preferences, but, on the other hand, they already contain the future having-being-born, when they are prospected as later being the sign for the child to go to sleep (Hirschauer et al. 2014: 159). The interpretation of bodily movements shows that presentifications are also linked to future prospectiveness. Thus, the presentifications described here represent a strong continuity of prenatal being, which also raises expectations of a postnatal continuation of presentifying characterizations.

\section{Cultivating Open Futures}

When the prenatal entity is presentified through ultrasound examinations or physical sensations, a continuity between this entity and a future child is assumed: the present experiences during an ultrasound and witnessing prenatal movements, structure the ready-to-hand knowledge, as a typified process of childhood development. The idealization of the "and so forth and so on" assume a certain future course of events. In and through the practices of presentification, the unborn is already perceived as what it is expected to be in the future. However, pregnant couples' stories show, that establishing such continuity between the present prenatal entity and the future child is not always successful or desired. Pregnant women can perceive bodily sensations and visible impulses of the prenatal entity as strange and disgusting (Sänger et al. 2013). This can lead to associations such as "dangerous aliens," instead of a "beloved child". Feelings of disgust and alienation "are difficult to be brought under the norm of a pregnant woman, who enjoys the perception of child movements" (Sänger et al. 2013: 62). This problematization refers to the idea of continuous development from the embryo to a child, which nevertheless allows a fundamental difference between the two: a foreign "parasite" threatening the physical integrity (Hirschauer et al. 2014: 250) and the child, it will nevertheless be born one day.

Less conflicting with parental norms seems to be the fact, that many (co-)pregnants do not immediately refer to the early visual representations of the unborn in ultrasound as "child" or "baby," but rather as "poppy seed," "small dot" or "cell clusters" (Sänger 2010: 55). In contrast to what Boltanski observed in the comparison of ultrasound examinations before abortions and the case of intentional pregnancies, such terms are thus not limited to 'tumorous' fetuses intended for abortion (Boltanski 2013: 127). They show that expecting parents do not identify the entity shown to them in the first sonographic visualizations, unbrokenly with the child that it is to become. In these descriptions, it is clearly expressed that that entity is not yet perceived as a child. For some pregnant couples, their descriptions of early bodily ("parasite") and visual ("little dot") impressions become "protonames" i.e., "practical precursors of personal names" (Hirschauer et al. 2014: 249). On the one hand, they grant "delay of specifications" (Hirschauer et al. 2014: 249)—-they can thus be used at a time when a name for the future child, which it will carry throughout its entire life, has not been found or chosen. On the other hand, they refer to the open horizons of pregnancies, describing "transitory objects [...] whose ontological status 
is changing or unclear" (Hirschauer et al. 2014: 250). With their not yet, protonames simultaneously refer to a but already, namely that there is already something there that wants to be named and addressed, although it does not yet have a gender or a body. Accordingly, the naming practice of some expecting parents changes with an increasing fixation of the unborn: the "little one" suddenly loses its openness with the medical sex determination and acquires a clarity that makes preliminary protonames unnecessary. The prenatal entity becomes, for example, "Carlos" and thus, the bearer of the name the couple had already chosen for an imagined child in their future, even before the pregnancy (Hirschauer et al. 2014: 251f.). However, many expecting parents still stick with protonames even if the sex and the future name have already been determined: what is now the 'Little Drummer' will only get its 'real' name after birth (Hirschauer et al. 2014: 253). This shows that expecting parents, despite all presentification and fixations, can maintain the openness of the prenatal entity and retain birth as an ontological border and moment of truth. Therefore, doubt and uncertainties are not put in brackets at this point (Schutz 1945: 551). On the contrary: doubts and uncertainty as well as plurality and openness are integrated. By cultivating these open futures, reaching out to the "world within my potential reach" (Schutz 1945: 547) is postponed. The parents wait until after birth, when the (un)born child enters the sphere of action of their direct "manipulatory area" (Schutz 1945: 547).

Some pregnant couples' wish to not find out their unborn's sex can be correspondingly interpreted. Wording during prenatal diagnoses indeed shows that prenatal diagnoses have a prognostic character: "It will be a girl," "your child will be disabled". ${ }^{10}$ However, almost inevitably, prenatal sex assignment points future expectations in a specific direction. Thought with Schutz, with a sonographic gender diagnosis, the knowledge about an unborn's gender moves out of the realm of complete not-knowing, a hunch, or a more or less vague feeling towards a certainty (Schutz 1959: 77f.). Thus, the expectations of a future life with a daughter or a son are aligned. Even if a doctor's sex diagnosis is only formulated in the form of an assumption or hint, it involuntarily modifies the previously fluid expectations and expecting couples lose their "neutrality" and "impartiality" [Unvoreingenommenheit] regarding the unborn's gender (Hirschauer et al. 2014: 184f.). Especially queer parents-to-be make use of the legitimacy of 'not-knowing' the sex of an unborn and thereby delay the gendering of their child (Dionisius 2020: 86). In other cases, not wanting to know the unborn's sex can also stem from fearing a false diagnosis: the pregnant couple becomes attached to a name, perhaps buy specifically accentuated baby clothes, possibly develop "postferences" (Hirschauer et al. 2014: 199) for the diagnosed child sex, which puts them at risk of having a "wrong" child, in the case of misdiagnosis. Therefore, some couples prefer to cultivate the open horizons of pregnancy by not wanting to know the sex of the child, prolonging the limbo in which an unborn's sex is unassigned.

\footnotetext{
${ }^{10}$ In her study on the situations of the ultrasound consultation, Heimerl (2013) points out a linguistic peculiarity because "diagnoses are always present time findings" (Heimerl 2013: 168). However, in the case of unborn children, they seem to "only become 'effective' at birth" (Heimerl 2013: 168).
} 
While many pregnancy practices are oriented towards a fixation and presentification of the unborn and produce reliability of expectations, some practices celebrate the open horizons of pregnancy and the "not-yet". Through this, the future birth is established as a moment of disclosure, in which, speaking with Duden, only then the "truth" of the unborn is to be revealed.

\section{Breaking Points: Prenatal Losses and Lost Futures}

When pregnancies end in miscarriage or stillbirth, the strong orientation towards the future, that characterizes pregnancies, becomes apparent in a critical manner. Such pregnancy courses break with the typification of pregnancy as becoming a child, and with the idealization of "and so forth and so on" because the prenatal entity loses its future as a child, that was expected and wanted for it. This (again) destabilizes the status of the prenatal entity. Similar to the "phase of perhapsability" (Schadler 2013) at the beginning of pregnancy, the establishment of a pregnancy loss is often characterized by ambiguity. With the onset of bleeding, pain, lack of internal bodily movement, and knowledge of the possibility of miscarriage, the pregnancy and the condition of the unborn become uncertain. Due to the "inwardness of dying" [Inwändigkeit des Sterbens] (Böcker 2017: 153), which is difficult to perceive, the prenatal entity often initially finds itself in a corridor between life and death, until the interpretation of the pregnancy loss is established through the combination of somatic sensations, such as the absence of movement, and the visual representation of motionlessness in ultrasound (Wettmann 2020). Here, uncertainty and vagueness can shape the knowledge of the future of the prenatal entity as well, once again putting pregnant couples in a temporal mode of waiting and worrying. ${ }^{11}$

However, even after the loss of a pregnancy is established, these entities show an openness of status that is directly based on the temporal structure of pregnancies as processes of becoming: particularly early miscarriages are characterized by the fact that it is unclear what is actually 'lost' here. Sociologist writers speak of a "loss of possibilities" (Frost et al. 2007), as "lost futures" (Murphy 2010) or as "mourning the dreams" (Malacrida 1998), characterizing not only the ambiguous nature of such experiences, but also the closeness of prenatal entities to the realm of phantasies, dreams and hopes, e.g., the "various worlds of phantasms" (Schutz 1945: 555), which prenatal death can induce, as a kind of disillusionment of the typified course of events. As one of Murphy's participants states: "I feel like almost I dreamt the whole pregnancy "cos there is nothing at the end of it" (Murphy 2010: 136). For even if the prenatal entity has already been constituted as an "inward other" and as a singularized personality, the loss of its future as a child and as a member of society

\footnotetext{
11 Similarly, the prenatal diagnosis of malformations can create such uncertainties. If it becomes clear that 'something is not normal', formerly envisioned futures and imaginations of the child are called into question and the general openness of the future becomes particularly acute. Feith and Marquardt (2017) show how the knowledge of an unborn child's malformation creates different forms of uncertainty for medical professionals and parents, coining their social construction of the child.
} 
can call into question the sense making activities, that have so far been conducted, and that, as shown above, always also refer to the child as an alive and living one.

A break with this expectation requires a reconstruction process, in which the past and the present must be reinterpreted and new drafts of the future must be developed, sometimes hardly disrupting the continuity and identity of the (pre)natal entity. For example, the apparition of the entity's corporal materiality after birth can bring up such incongruencies, when this direct presentification doesn't fit the former imaginations and is less (or more) child-like than expected (Böcker 2017: 149). If a couple refrains from giving the stillborn the name, they had chosen for the "child that it should once have become," this clearly highlights the fracture between the entity, that is materially presentifed with its being born, and the "child of the past future" (Völkle 2021: 124), shaped by the optative. The paradoxical temporality of pregnancy collapses, and the 'loss of future' unsettles the ontological status of the prenatal entity.

In other cases, a continuity between the entity before and after its prenatal death is achieved. Some parents, for example, narrate the time of pregnancy as the biography of the child (Böcker 2016: 324) and thereby counter the notion of a lost future with a past pregnancy that was meaningful in itself. ${ }^{12}$ Often, pregnancy tests, ultrasound images, and items like clothing and toys are kept as mementos and serve as proof of existence (Lupton 2013: 88f.) showing that "he was a real baby with baby things" (Layne 2000). These not only allow for coping with death and provide a spatialization and legitimization of grief (Böcker, 2016: 332) but also serve to stabilize parental identity as "the self-image as (having been) parents" (Böcker 2016: 336). Midwives also contribute to the construction of the prenatal entity as deceased children. By washing and dressing the stillborn fetus and encouraging parents to hold it, prenatal entities are ascribed a childlike existence (Völkle 2021; Wettmann 2021). The lost future is reformulated in the present, as the stillborn and its not-to-be-parents are brought into a shared present, enabling stabilization of their identities-as a (deceased) child and its parents. This perception of a pregnancy loss ties in with and continues the work on biographies of a child and parents during pregnancy, thus constructing a social identity "beyond the womb and the tomb" (Hockey and Draper 2005). Even if prenatal death appears as a crisis, a continuity between prenatal entity and born child can be achieved.

"In all societies and at all times, man stands "in the midst of death" (Schutz and Luckmann 1989: 129), and this also applies to pregnancies and their prenatal entities. As in everyday life, death is attempted to be excluded during pregnancy thus limiting future openness. Loss of pregnancy exposes these open horizons of future in a crisis-like manner by disrupting formed expectations about the future course of events and revealing the non-linear structure of sense making processes: in the course of events, they are subject to constant revision, readjustment, and

\footnotetext{
12 Some pregnant women who receive a fatal prognosis for their unborn child, decide to carry on with the pregnancy (sometimes despite feeling the expectation to do otherwise) and practice "being-a-mother in becoming-a-mother" (Rost 2015: 223). When a pregnancy loses its meaningfulness as a process leading to future relations to a born child, its sense of meaning as a present social relation can increase.
} 
restructuring. Only in the event of a crisis, do these come into consciousness, disrupting the natural attitude.

\section{Conclusions}

Cultural and medicalization research on pregnancy has convincingly demonstrated how medical models and technologies influence pregnancy's temporal order: they shape today's notion of pregnancy as a linear, nine-month-long developmental process that leads to the birth of an already prenatally existing child. Through ultrasound technology and prenatal examinations, prenatal entities have thus gained a present 'being' as a developing, unborn child. Simultaneously, the open futures of pregnancy were normatively limited to one future, namely that of a child's birth. While these ideas undoubtedly greatly influence the participants' interpretations, such a culturalist perspective on time alone does not do justice to the phenomenon's lived tensions. A reconstruction of pregnancies and prenatal entities oriented in this way undermines the temporal complexity of the phenomenon. Although participants are oriented to the linear temporality of biological, developmental models, they repeatedly undermine it. In this paper, we have instead proposed to examine pregnancy processes with an understanding of time that is open to discontinuities, concerning their temporal references and their effects on the constitution and construction of prenatal entities. As we have shown in our draft of a time-sociological understanding of pregnancy, pregnancies are characterized by a seemingly paradoxical temporality and can be understood as a process composed of zig-zag lines between past, present, and future. In the process of pregnancy, the unborn and its parents constantly experience new modifications and reformulations. In and with different modes of temporal references, the unborn's ontological status and parental being-and-becoming changes.

In parental imaginations, parenthood and the prenatal entity present themselves as open fantasies of the future, which can be playfully discarded and rejected, but at the same time, can contribute significantly to the co-active process of getting pregnant. The (in)activity of bodily processes, experienced as passivity, produces temporal references that constitute parenthood, and the prenatal entity, as an uncertain future event to wait for, cannot and should not be overtaken by hasty present activities. Presentification practices, such as the visualizations by ultrasound, and the physical sensing of the unborn, bring the prenatal entity into the present as an unborn child and into the pregnant couple's everyday life as beginning parents. However, these presentifications always point to a common future; only against the background of the future birth can the prenatal entity become an inward other. While this concerns the closing of open futures, there are also temporal references that cultivate the open horizons of pregnancy and the prenatal entity-which is not yet the child that is to be born-and thus preserve and celebrate an indeterminate instance of having children. Loss of pregnancy represents a break with the interpretative frameworks and definitions of the situation oriented towards a future as a child and parents. Miscarried and stillborn entities have no future as society members, rejecting past constructions and destabilizing the prenatal entity's status. Thus, it is 
clear that participants are not oriented solely to continuous development, but that the back and forth in time that accompanies the process of pregnancy involves anticipation, reformulation, tension, and breaks. The seemingly paradoxical temporal modes of reference have the effect of overcoming and generating contingency.

These interwoven temporal references, highlight pregnancies as processes of beginning. Just as Schutz's "stranger" is a "man without a history" (1944: 502) to the group he approaches, a prenatal entity too has no past, which could provide a basis for developing expectations. Meaningful references to a prenatal entity can only be established through the anticipation that there will be a child, with whom one will have a relationship as future parents. These, in turn, can become the common (pregnancy) history and narrative constituting a relationship in the first place. Furthermore, this already highly complex process is, at the same time, always marked by the possibility that things could turn out differently. Thus, the tensions, contingencies, and paradoxical temporalities that we can observe in the case of pregnancies and prenatal entities are not a pregnancy-specific phenomenon but also characterize other forms of relationship initiation, such as emerging friendships and romantic relationships. Because pregnancies represent a potential new beginning in two ways - the beginning of a relationship and of a person, a time sociological perspective is particularly insightful.

Acknowledgements We would like to thank the two anonymous reviewers for helpful comments, Marisa Herold for assistance with English language editing and our colleagues in Giessen and Mainz for insightful discussions.

Funding Open Access funding enabled and organized by Projekt DEAL.

Open Access This article is licensed under a Creative Commons Attribution 4.0 International License, which permits use, sharing, adaptation, distribution and reproduction in any medium or format, as long as you give appropriate credit to the original author(s) and the source, provide a link to the Creative Commons licence, and indicate if changes were made. The images or other third party material in this article are included in the article's Creative Commons licence, unless indicated otherwise in a credit line to the material. If material is not included in the article's Creative Commons licence and your intended use is not permitted by statutory regulation or exceeds the permitted use, you will need to obtain permission directly from the copyright holder. To view a copy of this licence, visit http://creativecommons.org/licen ses/by/4.0/.

\section{References}

Beck, U. (1992). Risk society: Towards a new modernity. Sage.

Berger, P. L., \& Luckmann, T. (1966). The social construction of reality: A treatise in the sociology of knowledge. Anchor Books.

Bergmann, W. (1992). The problem of time in sociology: An overview of the literature on the state of theory and research on the 'sociology of time', 1900-82. Time Society, 1(1), 81-134.

Bongaerts, G. (2020). Passive Aktivität. In R. Kurilla, K. Kolb-Albers, H. Krämer, \& K. Pitsch (Eds.), Sine Ira et Studio. Disziplinenübergreifende Annäherungen an die zwischenmenschliche Kommunikation (pp. 141-153). Springer.

Böcker, J. (2016). Frühe Tode. Verräumlichungen der Trauer um Ungeborene. In T. Benkel (Ed.), Die Zukunft des Todes: Heterotopien des Lebensendes (pp. 317-338). Transcript.

Böcker, J. (2017). Inwändig, unsichtbar, liminal. Ambivalenzen pränataler Verluste. In N. Jakoby \& M. Thönnes (Eds.), Zur Soziologie des Sterbens (pp. 135-156). Springer. 
Boltanski, L. (2013). The foetal condition: A sociology of engendering and abortion. Cambridge.

Burkart, G. (2002). Entscheidung zur Elternschaft revisited. Was leistet der Entscheidungsbegriff für die Erklärung biographischer Übergänge?. In N. F. Schneider \& H. Matthias-Bleck (Eds.), Elternschaft heute. Gesellschaftiche Rahmenbedingungen und individuelle Gestaltungsaufgaben (pp. 23-48). Leske und Budrich.

Burzan, N., \& Schöneck, N. M. (2002). Zeit. In G. Endruweit, G. Trommsdorff, \& N. Burzan (Eds.), Wörterbuch der Soziologie (pp. 638-639). UVK.

DiCaglio, S. (2017). Staging embryos: Pregnancy, temporality and the history of the Carnegie stages of embryo development. Body \& Society, 23(2), 3-24.

Dionisius, S. (2020). Zwischen Trans*-Empowerment und Cisnormativität: Leibliches in Elternwerden Grenzbereichen. In A. Peukert, J. Teschlade, E. Holzleithner, M. Motakef, \& C. Wimbauer (Eds.), Sonderheft GENDER: Elternschaft und Familie/n jenseits von Heteronormativität und Zweigeschlechtlichkeit (pp. 77-91). Barbara Budrich.

Duden, B. (1993). Disembodying women: Perspectives on pregnancy and the unborn. Harvard University Press.

Duden, B. (2002). Zwischen 'wahrem Wissen' und Prophetie: Konzeptionen des Ungeborenen. In B. Duden, J. Schlumbohm, \& P. Veit (Eds.), Geschichte des Ungeborenen: Zur Erfahrungs-und Wissenschaftsgeschichte der Schwangerschaft, 17-20, Jahrhundert (pp. 11-48). Vandenhoeck \& Ruprecht.

Durkheim, E. (1995). The elementary forms of the religious life. The Free Press.

Draper, J. (2002). 'It was a real good show': The ultrasound scan, fathers and the power of visual knowledge. Sociology of Health \& Illness, 24(6), 771-795.

Feith, D., \& Marquardt, B. (2017). Ungewisse Zukünfte am Lebensbeginn. Die soziale Konstruktion eines Kindes unter den Bedingungen einer pränatal diagnostizierten Fehlbildung. In Tsantsa. TSANTSA-Zeitschrift der Schweizerischen Ethnologischen Gesellschaft (Vol. 22, pp. 57-67).

Fischer, J. (2011). Gesellschaftskonstitution durch Geburt-Gesellschaftskonstruktion der Geburt. Zur Theorietechnik einer Soziologie der Geburt. In P.-I. Villa, S. Moebius, \& B. Thiessen (Eds.), Soziologie der Geburt: Diskurse, Praktiken und Perspektiven (pp. 22-37). Campus Verlag.

Fleck, L. (1979). Genesis and development of a scientific fact. The University of Chicago Press.

Frost, J., Bradley, H., Levitas, R., Smith, L., \& Garcia, J. (2007). The loss of possibility: Scientisation of death and the special case of early miscarriage. Sociology of Health \& Illness, 29(7), 1003-1022.

Heimerl, B. (2013). Die Ultraschallsprechstunde. Eine Ethnografie pränataldiagnostischer Situationen. Transcript.

Heimerl, B., \& Hofmann, P. (2016). Wie konzipieren wir Kinderkriegen?. Zeitschrift für Soziologie, 45(6), 410-430.

Hirschauer, S., Heimerl, B., Hoffmann, A., \& Hofmann, P. (2014). Soziologie der Schwangerschaft: Explorationen pränataler Sozialität. Lucius \& Lucius.

Hockey, J., \& Draper, J. (2005). Beyond the womb and the tomb: Identity, (dis)embodiment and the life course. Body \& Society, 11(2), 41-57.

Husserl, E. (1928/2000). Vorlesungen zur Phänomenologie des inneren Zeitbewußtseins (Vol. 3). De Gruyter.

Kreyenfeld, M., \& Schulz, F. (2018). Zeitverwendung in der Familie. Einleitung in das Schwerpunktthemenheft. Journal of Family Research, 30(1), 3-8.

Layne, L. L. (2000). 'He was a real baby with baby things' a material culture analysis of personhood, parenthood and pregnancy loss. Journal of Material Culture, 5(3), 321-345.

Lindemann, G. (2002). Die Grenzen des Sozialen: Zur sozio-technischen Konstruktion von Leben und Tod in der Intensivmedizin. Fink.

Lindemann, G. (2016). In Sorge und aus Lust. In A. Henkel, I. Karle, G. Lindemann, \& M. Werner (Eds.), Dimensionen der Sorge (pp. 73-98). Nomos.

Luckmann, T. (1970). On the boundaries of the social world. In M. Natanson (Ed.), Phenomenology and social reality. Essays in memory of Alfred Schutz (pp. 73-100). Martinus Nijhoff.

Luhmann, N. (1979). Zeit und Handlung-Eine vergessene Theorie. Zeitschrift für Soziologie, 8(1), 63-81.

Malacrida, C. (1998). Mourning the dreams: How parents create meaning from miscarriage, stillbirth, and early infant death. Routledge.

Lupton, D. (2013). The social world of the unborn. Palgrave Pivot.

Mead, G. H. (1926). The objective reality of perspectives. In E. S. Brightman (Ed.), Proceedings of the 6th international congress of philosophy (pp. 75-85). Longmans, Green and Co.

Montagu, A. (1989). Growing Young (2nd ed.). Bergin \& Garvey Publishers. 
Murphy, S. (2010). Lost futures: Stillbirth and the social construction of grief. Lambert.

Orland, B. (2003). Der Mensch entsteht im Bild. Postmoderne Visualisierungstechniken und Geburten. In H. Bredekamp, M. Bruhn, \& G. Werner (Eds.), Bilder in Prozessen (pp. 21-32). De Gruyter.

Paris, R. (2001). Warten auf Amtsfluren. Kölner Zeitschrift für Soziologie und Sozialpsychologie, 53(4), $705-733$.

Reckwitz, A. (2016). Kreativität und soziale Praxis. Studien zur Sozial-und Gesellschaftstheorie.. Transcript.

Reckwitz, A. (2020). Society of singularities. Polity Press.

Rentmeester, C., \& Hogan, A. (2020). Are you ready to meet your baby? Phenomenology, pregnancy, and the ultrasound. Journal of Applied Hermeneutics 2020, 1-13.

Rost, K. (2015). Wenn ein Kind nicht lebensfähig ist. University dissertation. Universitätsverlag, Osnabrück.

Sänger, E. (2010). "Einfach so mal schauen, was gerade los ist." Biosoziale Familialisierung in der Schwangerschaft. In K. Liebisch \& U. Manz (Eds.), Leben mit den Lebenswissenschaften. Wie wird biomedizinisches Wissen in Alltagspraxis übersetzt? (pp. 43-61). Transcript.

Sänger, E., Dörr, A., Scheunemann, J., \& Treusch, P. (2013). Embodying Schwangerschaft. Pränatales Eltern-Werden im Kontext medizinischer Risikodiskurse und Geschlechternormen. Gender: Zeitschrift für Geschlecht, Kultur und Gesellschaft, 5(1), 56-71.

Schadler, C. (2013). Vater, Mutter, Kind werden: Eine posthumanistische Ethnographie der Schwangerschaft. Transcript.

Schutz, A. (1944). The stranger: An essay in social psychology. American Journal of Sociology, 49(6), 499-507.

Schutz, A. (1945). On multiple realities. Philosophy and Phenomenological Research, 5(4), 533-576.

Schutz, A. (1951). Choosing among projects of action. Philosophy and Phenomenological Research, 12(2), 161-184.

Schutz, A. (1959). Tiresias, or our knowledge of future events. Social Research, 26(1), 71-89.

Schutz, A., \& Luckmann, T. (1973). The structures of the life world (Vol. I). Northwestern University Press.

Schutz, A., \& Luckmann, T. (1989). The structures of the life world (Vol. II). Northwestern University Press.

Seyfert, R. (2019). Beziehungsweisen. Elemente einer relationalen Soziologie.. Weilerswist-Metternich.

Sorokin, P. A., \& Merton, R. K. (1937). Social time: A methodological and functional analysis. American Journal of Sociology, 42(5), 615-629.

Strauss, A. (1959). Mirrors and masks. The search for identity. The Free Press.

Subrt, J. (2001). The problem of time from the perspective of the social sciences. Czech Sociological Review, 9(2), 211-224.

Verbeek, P.-P. (2008). Obstetric ultrasound and the technological mediation of morality: A postphenomenological analysis. Human Studies, 31(1), 11-26.

Villa, P.-I., Moebius, S., \& Thiessen, B. (2011). Soziologie der Geburt: Diskurse, Praktiken und Perspektiven. Campus.

Völkle, L. (2021). Die Existenzweisen eines Fötus. Eine Einzelfallanalyse zu Prozessen der De/Personalisierung und De/Humanisierung bei Totgeborenen. Zeitschrift für Soziologie 50(2), 114-130. https://doi.org/10.1515/zfsoz-2021-0009.

Wettmann, N. (2020). Somatisch-visuelle Aushandlung embryonalen Lebens. Zur Konstitution embryonaler Wesen am Beispiel Exitus im Uterus. In H. Ahner, M. Metzger, \& M. Nolte (Eds.), Von Mensch und Maschinen. Proceedings der 3. Tagung des Nachwuchsnetzwerks, INSIST (pp. 77-91). SSOAR. https://nbn-resolving.org/urn:nbn:de:0168-ssoar-67663-1.

Wettmann, N. (2021). »Geburt und Tod liegen ja sehr dicht beieinander.« Eine empirische Analyse zum pränatalen Tod im Denkstil von Hebammen. In T. Benkel \& M. Metzler (Eds.), Wissenssoziologie des Todes (pp. 268-291). Beltz Juventa.

Zechmeister, I. (2001). Foetal images: the power of visual technology in antenatal care and the implications for women's reproductive freedom. Health Care Analysis, 9(4), 387-400.

Publisher's Note Springer Nature remains neutral with regard to jurisdictional claims in published maps and institutional affiliations. 